\title{
The Influence of Modified Atmosphere Packaging on Quality Properties of Kiwifruits During Cold Storage and Shelf Life
}

\author{
Burhan ÖZTÜRK ${ }^{1}$, Erdal AĞLAR ${ }^{2 *}$
}

\begin{abstract}
This study was carried out to evaulate the effects of different modified atmosphere packagings (MAPs) on quality characteristics of kiwifruit (Actinidia deliciosa cv. 'Hayward') during cold storage and shelf life. In the study, 4 different MAP were selected as Xtend, Aypek, Fresh and FreshPlus. Kiwifruit were stored at $0 \pm 0.5^{\circ} \mathrm{C} 90 \pm 5 \% \mathrm{RH}$ during 180 days, and at $21^{\circ} \mathrm{C}, 70 \% \mathrm{RH}$ for shelf life (5 days). MAP treatment significantly delayed weight loss of kiwifruit during cold storage. In all treatments firstly respiration rate increased, but it abruptly decreased after 60 days of cold storage and shelf life. With MAP treatment, $\mathrm{L}^{*}$ value of skin color increased, whereas $\mathrm{L}^{*}$ values of flesh decreased. Xtend and FreshPlus treatments retarded losses of fruit firmness. MAP treated-fruit has got higher the values of titratable acidity and vitamin $C$ than control fruit. Results of study revealed that MAP treatments maintained fruit quality during cold storage and shelf life. But Aypek and Fresh MAP was more effective than other MAP treatments.
\end{abstract}

Keywords: Actinidia deliciosa, firmness, respiration rate, weight loss

\section{Kivide Depolama ve Raf Ömrü Süresince Modifiye Atmosfer Paketlemenin (Map) Meyve Kalite Özellikleri Üzerine Etkisi}

ÖZET:Bu çalışma, soğuk depo ve raf ömrü boyunca farklı modifiye atmosfer paketlemenin (MAP) kivi (Actinidia deliciosacv. 'Hayward') meyvelerinin kalite özellikleri üzerine etkisini belirlemek amacıyla yapılmıştır. Çalışmada Xtend, Aypek, Fresh ve FreshPlus olarak 4 farklı MAP seçilmiştir. Kivi meyveleri, 180 gün boyunca $0 \pm 0.5^{\circ} \mathrm{C}^{\prime}$ de ve $\% 90 \pm 5$ bağıl nemde ve raf ömrü süresince $(5$ gün) ise $21^{\circ} \mathrm{C}$ ve $\% 70$ bağıl nemde muhafaza edilmiştir. MAP uygulaması soğuk depolama sırasında kivi meyvesinin ağırlık kaybını önemli ölçüde geciktirmiştir. Bütün uygulamalarda depolamanın başlarında solunum hızı artmış, ancak 60 günlük soğuk depolama ve raf ömründen sonra aniden azalmıştır. MAP uygulaması ile meyve kabuğu $L^{*}$ değeri artış gösterirken, meyve eti $L^{*}$ değeri azalmıştır. Xtend ve FreshPlus uygulamaları meyve sertlik kaybını geciktirmiştir. MAP uygulanmış meyvelerin titreedilebilir asitlik ve $\mathrm{C}$ vitamini içeriği kontrol meyvelerinkinden daha yüksek bulunmuştur. Araştırma sonuçları, MAP uygulamalarının soğuk depolama ve raf ömrü boyunca meyve kalitesini koruduğunu ortaya koymuştur. Fakat Aypek ve Fresh MAP diğer MAP uygulamalarından daha etkili bulunmuştur.

Anahtar Kelimeler: Actinidia deliciosa, sertlik, solunum oranı, ağırlık kaybı

\footnotetext{
${ }^{1}$ Erdal AĞLAR (Orcid ID:0000-0001-2345-6789), Ordu Üniversitesi, , Ziraat Fakültesi Bahçe Bitkileri Bölümü, Altınordu, Ordu ${ }^{2}$ Burhan ÖZTÜRK (Orcid ID: 0002-0002-0867-3942) Sivas Cumhuriyet Üniversitesi, Suşehri Timur Karabal Meslek Yüksekokulu, Organik Tarım Bölümü, Suşehri, Sivas

*Sorumlu Yazar: Erdal AĞLAR, e-mail: erdalaglar@gmail.com

Bu çalışma 12-18 Ağustos 2018 tarihleri arasında İstanbul'da düzenlenen olan XXX. INTERNATIONAL HORTICULTURAL CONGRESS' de poster olarak sunulmuştur.
} 


\section{INTRODUCTION}

With its high content of vitamin $\mathrm{C}$ and phytochemicals like chlorophyl, flavonoid, carotenoid, phenolics and capacity of strong antioxidants, consumption of kiwifruit has been increasing in recent years (Cassano et al., 2006). Kiwifurit is a climacteric fruit that can be stored in low temperatures for long periods (at $0{ }^{0} \mathrm{C}$ for 4-6 month) but it can also be significantly softened when it is exposed to even very little amounts of ethylene (Yang and Lim, 2017). That is the most significant reasons, which cause the losses of the product.

Post-harvest longevity can be extended by harvesting high quality fruit at harvest time and preserving them with appropriate cold storage techniques. Fruit firmness is the most significant fruit quality characteristic, which affects storage period and fruit softening (Pekmezci et al., 2004). Many physiological processes such as swelling and deterioration of cell walls, hydrolysis of starch, decrease in water and osmotic potential cause softening in kiwifruit (Redgwell and Fry, 1993). During ripening and cold storage, kiwifruit is exposed to biochemical changes such as transformation of starch to sugar and alterations in cell walls that account for texture, taste and aroma of fruit. To extend the post-harvest longevity of kiwifruit, the shelf life of fruit can be prolonged with pre-harvest treatments, which improve fruit quality (Valverde et al., 2015), and post-harvest treatments, which reduce the fruit quality losses (Petracek et al., 2002; Chiabrando, 2013; Valero et al., 2014).

To prolong the storage period of fruit after harvest, packaging technologies as MAP are used. With the MAP treatment, the modified atmosphere, which has a low oxygen content, high carbon dioxide content and moisture, is formed around the product (Guilbert et al., 1996). This directly influences respiration rates of the fruit and vegetables, reduce ethylene synthesis of the fruit and retards ripening process
(Cantin et al. 2008). In this study, it is aimed to determine the effects of MAP on post-harvest performance and storage of kiwifruit.

\section{MATERIAL AND METHOD}

\section{Plant material}

In the study, the kiwifruit harvested from 10-year old Hayward (Actinidia deliciosacv. 'Hayward') trees grafted on seedling rootstocks were used. Fruit were hand-harvested in $6.5 \%$ soluble solids content (SSC). Fruit with uniform shape and size and no scars were selected. Fruit were immediately transported at $10 \pm 1.0{ }^{\circ} \mathrm{C}$ and $80 \pm 5.0$ for $0.5 \mathrm{~h}$ by a frigorific vehicle to postharvest physiology laboratory of Horticulture Department of Ordu University.

\section{Method}

At harvest, 30 fruit were used for analysis. For cold storage and shelf life analysis, treatments were designed as control (without MAP), Xtend, Aypek, Fresh and FreshPlus. Samples of $5 \mathrm{~kg}$ fruit were placed in 18 boxes for each treatment. Three packages were used for each analysis period as a package for each replicate. Half of them $(2.5 \mathrm{~kg})$ was used for analyses in the cold storage, and the rest was used for analyses in the shelf life (5 days at $21 \pm 1.0{ }^{\circ} \mathrm{C}$ and $\left.70 \pm 5 \% \mathrm{RH}\right)$. The fruit were stored at $0 \pm 0.5{ }^{\circ} \mathrm{C}$ and $90 \pm 5 \% \mathrm{RH}$ for 180 days (day 30, 60, 90, 120, 150, and 180), and analyzed at 30 day intervals.

\section{Weight loss}

Fruit weight was determined by using a digital scale ( $\pm 0.01 \mathrm{~g}$ ) (Radvag PS $4500 / \mathrm{C} / 1$, Poland). Weight loss was determined by the difference between the initial and final weights of each replicate during cold storage and expressed as percent. Weight loss was replicated three times for each replication.

\section{Respiration rate, $\mathrm{O}_{2}$ and $\mathrm{CO}_{2}$ concentration}

For respiration rate, 5 fruit per chamber were sealed in a $2 \mathrm{~L}$ air-tight chamber fitted with a rubber septum for $1 \mathrm{~h}$ at $20 \pm 1{ }^{\circ} \mathrm{C}$ and $90 \% \mathrm{RH}$. 
Then the chamber was connected to a gas sensor (Vernier, Oregon, USA). The respiration rate was determined by measuring the amount of carbondioxide $\left(\mathrm{CO}_{2}\right)$ produced by the fruit. Gas concentration $\left(\mathrm{CO}_{2}\right.$ and $\left.\mathrm{O}_{2}\right)$ inside MAP was monitored using a gas analyzer (Abiss, model legend, France).

\section{Color characteristics and firmness}

Color characteristics ( $\mathrm{L}^{*}$, chroma and hue angle) were measured at opposite sides of each fruit with a colorimeter (Konica-Minolta, model CR-400, Japan). 10 fruit in each replication were used for color measurement. Chromatic analyses were conducted in accordance with the CIE (Commission Internationale de l'Eclairage) system. Values of $L^{*}, a^{*}$ and $b^{*}$ were used to define a three-dimensional color space. The chroma value was calculated with the formula $C^{*}=\left(\mathrm{a}^{* 2}+\mathrm{b}^{* 2}\right)^{1 / 2}$, and the hue angle with $h^{\circ}=\tan ^{-1}$ $\mathrm{b}^{*} / \mathrm{a}^{*}$. Flesh firmness was determined on three sides of equatorial line of each fruit with a pressmounted Effegi penetrometer (FT 327, USA) with $11.1 \mathrm{~mm}$ tip. 10 fruit in each replication were used for texture measurement.

\section{SSC, titratable acidity and vitamin C}

For SSC, titratable acidity and vitamin C measurements, 15 fruit were selected from each replicate and fruit were divided into 3 groups with 5 fruit. The fruit juice was extracted with an electrical fruit juice extractor (HR1855/70, Philips, Turkey). A digital refractometer (PAL-1, McCormick Fruit Tech., Yakima, Wash., USA) was used to determine SSC (\% Brix). For titratable acidity, $10 \mathrm{ml}$ extract was diluted with $10 \mathrm{ml}$ distilled water, and then titrating to $\mathrm{pH} 8.2$ using $0.1 \mathrm{~mol} \mathrm{~L}^{-1}$ sodium hydroxide was

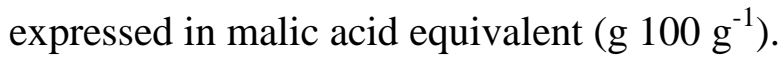

For vitamin $\mathrm{C}$ content, sufficient amount of extract was taken and resultant volume was completed to $5 \mathrm{ml}$ with the addition of $0.5 \%$ oxalic acid. Ascorbic acid test strip (Catalog no: 116981, Merck, Germany) was taken from reclose tube, dipped into the solution for 2 seconds and reflectometer set (Merck RQflex plus 10) was started. The test strip was then shaken off to remove excess liquid over it, waited for 8 seconds and reading was performed until the end of $15^{\text {th }}$ second. The resultant value was expressed as mg $100 \mathrm{~g}^{-1}$.

\section{Statistical analysis}

All statistical analyses were performed with SAS Version 9.1 (SAS, USA). Data normality was determined by the KolmogorovSmirnov test and the homogeneity of variances by the Levene's test. Data were analyzed by analysis of variance. Means were compared by Tukey's test at a significance level of 0.05 .

\section{RESULTS AND DISCUSSION}

\section{Weight Loss}

In the study conducted to determine the effects of MAP treatments on post-harvest longevity of kiwifruit, it is observed that MAP treatment has significant impact on weight loss during storage. After 180-day storage the lowest weight loss occurred in Aypek MAP treatment which was around $0.46 \%$, while in control group this value was around $6.32 \%$. In terms of weight losses, statistically important differences were observed between different MAP treatments. Aypek and Fresh MAP treatment was observed to be the most effective ones in preserving weight while the least effective one was determined to be FreshPlus treatment (Table 1). In parallel with the results of our study, Fonseca et al. (2002) stated that MAP treatment reduced weight losses in fruit during cold storage. Ağlar et al. (2017) reported that MAP treatment was a significant role in reducing weight loss in sweet cherry. Reduction of weight loss thanks to MAP treatment can be explained by reducing the effect of MAP on difference in water vapor between plant material and the air surrounding it. 
Table 1. Effects of different modified atmosphere packaging on weight loss of kiwifruit during cold storage and shelf life

\begin{tabular}{lcccccc}
\hline Treatments & \multicolumn{7}{c}{ Weight loss $(\%)$} \\
\cline { 2 - 6 } & 30 & 60 & 90 & 120 & 150 & 180 \\
\hline Control & $1.75 \mathrm{a}$ & $2.74 \mathrm{a}$ & $3.53 \mathrm{a}$ & $4.41 \mathrm{a}$ & $5.29 \mathrm{a}$ & $6.32 \mathrm{a}$ \\
Xtend & $0.31 \mathrm{c}$ & $0.60 \mathrm{c}$ & $1.04 \mathrm{c}$ & $1.35 \mathrm{c}$ & $1.63 \mathrm{c}$ & $1.93 \mathrm{c}$ \\
Aypek & $0.15 \mathrm{~d}$ & $0.27 \mathrm{~d}$ & $0.35 \mathrm{~d}$ & $0.37 \mathrm{~b}$ & $0.41 \mathrm{~d}$ & $0.46 \mathrm{~d}$ \\
Fresh & $0.18 \mathrm{~d}$ & $0.33 \mathrm{~d}$ & $0.40 \mathrm{~d}$ & $0.44 \mathrm{~b}$ & $0.49 \mathrm{~d}$ & $0.52 \mathrm{~d}$ \\
FreshPlus & $0.92 \mathrm{~b}$ & $1.80 \mathrm{~b}$ & $2.48 \mathrm{~b}$ & $3.35 \mathrm{~b}$ & $4.24 \mathrm{~b}$ & $5.11 \mathrm{~b}$ \\
\hline
\end{tabular}

Means in columns with the different letters are significantly different according to Tukey's test at $\mathrm{p}<0.05$

\section{Respiration Rate, $\mathrm{O}_{2}$ and $\mathrm{CO}_{2}$ Concentration}

With the MAP treatment, the modified atmosphere, which has a low oxygen content, high carbondioxide content and moisture, is formed around the product (Guilbert et al., 1996). This atmosphere reduces respiration rate, ethylene sensitivity and production, fruit decay and physiological changes, oxidation (Saltveit, 1997). MAP treatments have significant positive effects in storage of fruit (Petracek et al., 2002). In our study, changes in respiration rate were detected depending on storage period. Until the $60^{\text {th }}$ day of storage, in all treatments, increase in respiration rate was observed and after this period decrease began. Differences in respiration rate between treatments are found to be significant. At the end of cold storage, the lowest respiration rate was observed with the control, Fresh and FreshPlus treatments. Until the $90^{\text {th }}$ day of storage, while no significant difference between Aypek and control group occurred in terms of respiration rates, the other MAP treatments had higher respiration rate than control. On the $120^{\text {th }}$ day of storage, the highest respiration rate was obtained by FreshPlus treatment. At the end of storage, while fruit treated with Xtend showed the highest respiration rate, fruit treated with Freshplus had the lowest rate of respiration. There were not significant differences between control, Fresh and Fresh Plus treatment in terms of respiration rate at the end of storage. It was determined that
MAP treatments had a significant effect on controlling respiration rate during storage and shelf life. During shelf life, no significant differences in respiration rates between MAP treatments were detected (Table 2).

Effects of MAP treatments on atmospheric concentrations of oxygen and carbondioxide, which effect respiration rate was also evaluated and it is observed that MAP treatments were effective in controlling the oxygen concentration throughout storage. With MAP treatments, there were no significant differences between oxygen concentrations at the beginning and at the end of storage. In periodical measurements during the storage, the lowest oxygen concentration was recorded with Fresh treatment while differences between other three groups were not significant. On the $30^{\text {th }}$ day of storage, the highest carbondioxyde concentration was recorded and depending on storage period decrease in $\mathrm{CO}_{2}$ was observed. The lowest $\mathrm{CO}_{2}$ was recorded at the end of storage period. From one treatment to another, there have been significant differences of carbondioxyde concentration. In all measurements, while the highest carbondioxyde concentration was obtained in Aypek treatment, the lowest value was measured in Xtend treatment (Table 3). Mendoza et al. (2016) stated that $\mathrm{O}_{2}$ and $\mathrm{CO}_{2}$ concentrations can be kept under control with the help of postharvest technology like MAP 
Table 2. Effects of different modified atmosphere packaging on respiration rate of kiwifruit during cold storage and shelf life

\begin{tabular}{|c|c|c|c|c|c|c|c|}
\hline \multirow[t]{3}{*}{ Treatments } & \multicolumn{7}{|c|}{ Respiration rate $\left(\mathrm{mL} \mathrm{CO}_{2} \mathrm{~kg}^{-1} \mathrm{~h}^{-1}\right)$} \\
\hline & \multicolumn{7}{|c|}{ Cold storage $\left(0^{\circ} \mathrm{C}\right)$} \\
\hline & Harvest & 30 & 60 & 90 & 120 & 150 & 180 \\
\hline Control & 4.84 & $6.92 \mathrm{~b}$ & $15.04 \mathrm{~b}$ & $8.20 \mathrm{~b}$ & $7.50 \mathrm{c}$ & $5.20 \mathrm{~b}$ & $1.11 \mathrm{c}$ \\
\hline Xtend & 4.84 & $14.21 \mathrm{a}$ & $28.84 \mathrm{a}$ & $16.57 \mathrm{a}$ & $9.29 \mathrm{~b}$ & $8.41 \mathrm{a}$ & $2.78 \mathrm{a}$ \\
\hline Aypek & 4.84 & $7.63 \mathrm{~b}$ & $12.43 \mathrm{~b}$ & $10.02 \mathrm{~b}$ & $8.97 \mathrm{~b}$ & $7.55 \mathrm{a}$ & $1.92 \mathrm{~b}$ \\
\hline Fresh & 4.84 & $14.36 \mathrm{a}$ & $29.34 \mathrm{a}$ & $14.65 \mathrm{a}$ & $9.36 \mathrm{~b}$ & $7.10 \mathrm{a}$ & $1.20 \mathrm{c}$ \\
\hline \multirow[t]{3}{*}{ FreshPlus } & 4.84 & $16.87 \mathrm{a}$ & $33.76 \mathrm{a}$ & $15.32 \mathrm{a}$ & $12.68 \mathrm{a}$ & $8.54 \mathrm{a}$ & $1.01 \mathrm{c}$ \\
\hline & \multicolumn{7}{|c|}{ Shelf life $\left(21^{\circ} \mathrm{C}\right)$} \\
\hline & Harvest +5 & $30+5$ & $60+5$ & $90+5$ & $120+5$ & $150+5$ & $180+5$ \\
\hline Control & 5.62 & $13.11 \mathrm{a}$ & $21.60 \mathrm{a}$ & $12.05 \mathrm{a}$ & $10.15 \mathrm{a}$ & $8.86 \mathrm{a}$ & $5.55 \mathrm{a}$ \\
\hline Xtend & 5.62 & $9.65 \mathrm{~b}$ & $12.48 \mathrm{~b}$ & $9.23 \mathrm{~b}$ & $6.98 \mathrm{~b}$ & $6.77 \mathrm{~b}$ & $2.01 \mathrm{~b}$ \\
\hline Aypek & 5.62 & $8.97 \mathrm{~b}$ & $12.95 \mathrm{~b}$ & $8.19 b$ & $6.93 \mathrm{~b}$ & $5.24 \mathrm{~b}$ & $2.89 \mathrm{~b}$ \\
\hline Fresh & 5.62 & $8.66 \mathrm{~b}$ & $13.12 \mathrm{~b}$ & $9.82 \mathrm{~b}$ & $6.18 \mathrm{~b}$ & $5.31 \mathrm{~b}$ & $2.40 \mathrm{~b}$ \\
\hline FreshPlus & 5.62 & $12.36 \mathrm{a}$ & $14.23 \mathrm{~b}$ & $9.94 \mathrm{~b}$ & $7.46 \mathrm{~b}$ & $5.62 \mathrm{~b}$ & $2.33 \mathrm{~b}$ \\
\hline
\end{tabular}

Means in columns with the same letter do not differ according to Tukey's test at $\mathrm{P}<0.05$

Table 3. Effects of different modified atmosphere packaging on $\mathrm{O}_{2}$ and $\mathrm{CO}_{2}$ concentration of kiwifruit during cold storage

\begin{tabular}{|c|c|c|c|c|c|c|}
\hline \multirow[t]{2}{*}{ Treatments } & \multicolumn{6}{|c|}{$\mathrm{O}_{2}$ and $\mathrm{CO}_{2}(\%)$} \\
\hline & 30 & 60 & 90 & 120 & 150 & 180 \\
\hline & \multicolumn{6}{|c|}{$\mathrm{O}_{2}$} \\
\hline Xtend & $17.53 \mathrm{~b}$ & $19.07 \mathrm{a}$ & $19.57 \mathrm{a}$ & $19.93 \mathrm{a}$ & $19.17 \mathrm{a}$ & $19.50 \mathrm{a}$ \\
\hline Aypek & $18.50 \mathrm{~b}$ & $19.13 \mathrm{a}$ & $19.67 \mathrm{a}$ & $20.00 \mathrm{a}$ & $19.30 \mathrm{a}$ & $19.33 \mathrm{a}$ \\
\hline Fresh & $14.10 \mathrm{c}$ & $17.73 \mathrm{~b}$ & $17.83 \mathrm{~b}$ & $18.60 \mathrm{~b}$ & $18.17 \mathrm{~b}$ & $18.80 \mathrm{~b}$ \\
\hline \multirow[t]{2}{*}{ FreshPlus } & $22.27 \mathrm{a}$ & $19.67 \mathrm{a}$ & $19.97 \mathrm{a}$ & $20.23 \mathrm{a}$ & $19.60 \mathrm{a}$ & $19.43 \mathrm{a}$ \\
\hline & \multicolumn{6}{|c|}{$\mathrm{CO}_{2}$} \\
\hline Xtend & $2.03 \mathrm{c}$ & $0.90 \mathrm{c}$ & $0.60 \mathrm{c}$ & $0.47 \mathrm{c}$ & $0.37 \mathrm{c}$ & $0.40 \mathrm{c}$ \\
\hline Aypek & $3.17 \mathrm{a}$ & $1.87 \mathrm{a}$ & $1.23 \mathrm{a}$ & $1.03 \mathrm{a}$ & $0.87 \mathrm{a}$ & $0.87 \mathrm{a}$ \\
\hline Fresh & $2.17 \mathrm{c}$ & $1.07 \mathrm{c}$ & $0.93 \mathrm{~b}$ & $0.77 \mathrm{~b}$ & $0.60 \mathrm{~b}$ & $0.60 \mathrm{~b}$ \\
\hline FreshPlus & $2.57 \mathrm{~b}$ & $1.40 \mathrm{~b}$ & $0.93 \mathrm{~b}$ & $0.80 \mathrm{~b}$ & $0.67 \mathrm{~b}$ & $0.60 \mathrm{~b}$ \\
\hline
\end{tabular}

Means in columns with the same letter do not differ according to Tukey's test at $\mathrm{P}<0.05$

\section{Fruit Color}

In sweet cherry, fruit color is one of the most important parameters that determine fruit quality and customer preferences. That is why it is very important to preserve fruit color during storage. Aglar et al. (2017) stated that MAP treatments delayed colorization during storage and shelf life. In this study, when the effects of MAP treatment on color values were investigated, in proportion to storage period it was determined that $\mathrm{L}^{*}$ value decreased. It was observed that MAP treatments did not have a significant effect on $\mathrm{L}^{*}$ value during storage, however, on the $120^{\text {th }}$ and $180^{\text {th }}$ days of storage, differences between $L^{*}$ values of different treatments were detected. While on the $120^{\text {th }}$ and $180^{\text {th }}$ days of storage the highest values of $\mathrm{L}^{*}$ were measured in Xtend treatment, the lowest 
values were recorded in Fresh treatment on $120^{\text {th }}$ day and in control and Aypek groups on $180^{\text {th }}$ day. After $30^{\text {th }}, 90^{\text {th }}$ and $180^{\text {th }}$ days of storage, during shelf life there were no significant differences between $L^{*}$ values of different treatments. However, after 5-day shelf life, on the $60^{\text {th }}, 120^{\text {th }}$ and $150^{\text {th }}$ days of storage there were noticeable differences between $\mathrm{L}^{*}$ values of different treatments. In these measurements, the fruit treated with Xtend and FreshPlus had the highest $\mathrm{L}^{*}$ values, while the lowest $\mathrm{L}^{*}$ value was measured in control group (Table 4).

Table 4. Effects of different modified atmosphere packaging on $L^{*}$ values of kiwifruit during cold storage and shelf life

\begin{tabular}{|c|c|c|c|c|c|c|c|}
\hline \multirow[t]{3}{*}{ Treatments } & \multicolumn{7}{|c|}{$\mathrm{L}^{*}$} \\
\hline & \multicolumn{7}{|c|}{ Cold storage $\left(0^{\circ} \mathrm{C}\right)$} \\
\hline & Harvest & 30 & 60 & 90 & 120 & 150 & 180 \\
\hline Control & 62.28 & $61.18 \mathrm{a}$ & $60.52 \mathrm{a}$ & $58.39 \mathrm{a}$ & $57.45 \mathrm{~b}$ & $56.80 \mathrm{a}$ & $55.38 \mathrm{c}$ \\
\hline Xtend & 62.28 & $60.88 \mathrm{a}$ & $60.55 \mathrm{a}$ & $58.96 \mathrm{a}$ & $58.58 \mathrm{a}$ & $57.42 \mathrm{a}$ & $57.10 \mathrm{a}$ \\
\hline Aypek & 62.28 & $61.55 \mathrm{a}$ & $59.53 \mathrm{a}$ & $59.08 \mathrm{a}$ & $57.68 \mathrm{~b}$ & $57.49 \mathrm{a}$ & $55.30 \mathrm{c}$ \\
\hline Fresh & 62.28 & $61.26 \mathrm{a}$ & $59.46 \mathrm{a}$ & $58.43 \mathrm{a}$ & $56.86 \mathrm{c}$ & $56.82 \mathrm{a}$ & $56.46 \mathrm{~b}$ \\
\hline \multirow[t]{3}{*}{ FreshPlus } & 62.28 & $61.62 \mathrm{a}$ & $59.76 \mathrm{a}$ & $57.91 \mathrm{a}$ & $57.71 \mathrm{~b}$ & $57.18 \mathrm{a}$ & $57.09 \mathrm{a}$ \\
\hline & \multicolumn{7}{|c|}{ Shelf life $\left(21^{\circ} \mathrm{C}\right)$} \\
\hline & Harvest+5 & $30+5$ & $60+5$ & $90+5$ & $120+5$ & $150+5$ & $180+5$ \\
\hline Control & 61.87 & $57.50 \mathrm{a}$ & $56.40 \mathrm{c}$ & $56.25 \mathrm{a}$ & $55.36 \mathrm{~b}$ & $55.14 \mathrm{~b}$ & $45.46 \mathrm{a}$ \\
\hline Xtend & 61.87 & $58.75 \mathrm{a}$ & $57.54 \mathrm{~b}$ & $56.84 \mathrm{a}$ & $56.43 \mathrm{a}$ & 56.69 a & $45.87 \mathrm{a}$ \\
\hline Aypek & 61.87 & $58.55 \mathrm{a}$ & $57.90 \mathrm{~b}$ & $56.96 \mathrm{a}$ & $55.58 \mathrm{~b}$ & $55.54 \mathrm{~b}$ & $45.36 \mathrm{a}$ \\
\hline Fresh & 61.87 & $57.88 \mathrm{a}$ & $57.46 \mathrm{~b}$ & $56.67 \mathrm{a}$ & $55.58 \mathrm{~b}$ & $55.67 \mathrm{~b}$ & $45.05 \mathrm{a}$ \\
\hline FreshPlus & 61.87 & $58.21 \mathrm{a}$ & $58.61 \mathrm{a}$ & $55.65 \mathrm{a}$ & $56.67 \mathrm{a}$ & $56.58 \mathrm{a}$ & $45.57 \mathrm{a}$ \\
\hline
\end{tabular}

Means in columns with the same letter do not differ according to Tukey's test at $\mathrm{P}<0.05$

Table 5. Effects of different modified atmosphere packaging on chroma values of kiwifruit during cold storage and shelf life

\begin{tabular}{|c|c|c|c|c|c|c|c|}
\hline \multirow[t]{3}{*}{ Treatments } & \multicolumn{7}{|c|}{ Chroma } \\
\hline & \multicolumn{7}{|c|}{ Cold storage $\left(0^{\circ} \mathrm{C}\right)$} \\
\hline & Harvest & 30 & 60 & 90 & 120 & 150 & 180 \\
\hline Control & 41.80 & $38.79 \mathrm{~b}$ & $33.53 \mathrm{~b}$ & $31.94 \mathrm{~b}$ & $30.91 \mathrm{~b}$ & $30.42 \mathrm{~b}$ & $29.26 \mathrm{a}$ \\
\hline Xtend & 41.80 & $41.63 \mathrm{a}$ & $36.15 \mathrm{a}$ & $34.25 \mathrm{a}$ & $33.16 \mathrm{a}$ & $30.42 \mathrm{~b}$ & $28.25 \mathrm{a}$ \\
\hline Aypek & 41.80 & $38.53 \mathrm{~b}$ & $36.64 \mathrm{a}$ & $31.55 \mathrm{~b}$ & $30.79 \mathrm{~b}$ & $29.71 \mathrm{~b}$ & $28.99 \mathrm{a}$ \\
\hline Fresh & 41.80 & $37.61 \mathrm{~b}$ & $36.62 \mathrm{a}$ & $33.25 \mathrm{~b}$ & $30.34 \mathrm{~b}$ & $29.49 \mathrm{~b}$ & $28.84 \mathrm{a}$ \\
\hline \multirow[t]{3}{*}{ FreshPlus } & 41.80 & $41.15 \mathrm{a}$ & $37.95 \mathrm{a}$ & $33.94 \mathrm{a}$ & $33.03 \mathrm{a}$ & $31.80 \mathrm{a}$ & $28.66 \mathrm{a}$ \\
\hline & \multicolumn{7}{|c|}{ Shelf life $\left(21^{\circ} \mathrm{C}\right)$} \\
\hline & Harvest+5 & $30+5$ & $60+5$ & $90+5$ & $120+5$ & $150+5$ & $180+5$ \\
\hline Control & 41.61 & $38.64 \mathrm{a}$ & $35.42 \mathrm{~b}$ & $34.44 \mathrm{a}$ & $32.68 \mathrm{a}$ & $32.05 \mathrm{a}$ & $26.35 \mathrm{a}$ \\
\hline Xtend & 41.61 & $38.00 \mathrm{a}$ & $35.57 \mathrm{~b}$ & $34.56 \mathrm{a}$ & $31.75 \mathrm{a}$ & $30.28 \mathrm{a}$ & $26.06 \mathrm{a}$ \\
\hline Aypek & 41.61 & $38.20 \mathrm{a}$ & $35.53 \mathrm{~b}$ & $33.93 \mathrm{a}$ & $32.95 \mathrm{a}$ & $32.40 \mathrm{a}$ & $24.16 \mathrm{a}$ \\
\hline Fresh & 41.61 & $38.82 \mathrm{a}$ & $35.18 \mathrm{~b}$ & $32.50 \mathrm{a}$ & $32.26 \mathrm{a}$ & $31.93 \mathrm{a}$ & $25.91 \mathrm{a}$ \\
\hline FreshPlus & 41.61 & $37.78 \mathrm{a}$ & $37.64 \mathrm{a}$ & $34.25 \mathrm{a}$ & $32.43 \mathrm{a}$ & $32.46 \mathrm{a}$ & $26.14 \mathrm{a}$ \\
\hline
\end{tabular}

Means in columns with the same letter do not differ according to Tukey's test at $\mathrm{P}<0.05$

In proportion to storage period, chroma value has also decreased. Compared to control group, FreshPlus and Xtend MAP treatments have caused increase in chroma value, while the other two treatments (Aypek and Fresh) had no significant effect on chroma value. However, at 
the end of storage $\left(180^{\text {th }}\right.$ day) there were no statistically significant differences between chroma values of treatments. After storage, throughout shelf life, it was determined that MAP treatment had no an effect on chroma value of fruit (Table 5).

Both during cold storage and during shelf life, MAP treatment have not affected hue angle values (Table 6). The effect of MAP treatment on preserving color parameters during postharvest periods can be explained by the effect of MAP on gas permeability (Castellanos et al., 2016; Domínguez et al., 2016) and by decreasing activity of biochemical. MAP treatments have retarded the formation of the fruit color pigments such as carotenoids and anthocyanin (Artes-Hernandez et al., 2006).

Table 6. Effects of different modified atmosphere packaging on hue angle values of kiwifruit during cold storage and shelf life

\begin{tabular}{|c|c|c|c|c|c|c|c|}
\hline \multirow[t]{3}{*}{ Treatments } & \multicolumn{7}{|c|}{ Hue angle } \\
\hline & \multicolumn{7}{|c|}{ Cold storage $\left(0^{\circ} \mathrm{C}\right)$} \\
\hline & Harvest & 30 & 60 & 90 & 120 & 150 & 180 \\
\hline Control & 116.1 & $115.3 \mathrm{a}$ & $114.3 \mathrm{a}$ & $113.8 \mathrm{a}$ & $113.2 \mathrm{a}$ & $112.9 \mathrm{~b}$ & $111.6 \mathrm{~b}$ \\
\hline Xtend & 116.1 & $115.3 \mathrm{a}$ & $114.7 \mathrm{a}$ & $114.5 \mathrm{a}$ & $114.3 \mathrm{a}$ & $114.1 \mathrm{a}$ & $113.2 \mathrm{a}$ \\
\hline Aypek & 116.1 & $115.8 \mathrm{a}$ & $115.1 \mathrm{a}$ & $114.8 \mathrm{a}$ & $114.3 \mathrm{a}$ & 113.9 a & $112.6 \mathrm{a}$ \\
\hline Fresh & 116.1 & 115.9 a & $115.4 \mathrm{a}$ & $114.2 \mathrm{a}$ & $114.1 \mathrm{a}$ & $114.0 \mathrm{a}$ & $113.1 \mathrm{a}$ \\
\hline \multirow[t]{3}{*}{ FreshPlus } & 116.1 & $115.5 \mathrm{a}$ & $114.6 \mathrm{a}$ & $114.4 \mathrm{a}$ & $114.0 \mathrm{a}$ & 113.7 a & $112.6 \mathrm{a}$ \\
\hline & \multicolumn{7}{|c|}{ Shelf life $\left(21^{\circ} \mathrm{C}\right)$} \\
\hline & Harvest +5 & $30+5$ & $60+5$ & $90+5$ & $120+5$ & $150+5$ & $180+5$ \\
\hline Control & 115.1 & $114.1 \mathrm{a}$ & $113.1 \mathrm{a}$ & $111.3 \mathrm{~b}$ & $111.0 \mathrm{a}$ & $110.3 \mathrm{~b}$ & $109.1 \mathrm{~b}$ \\
\hline Xtend & 115.1 & $114.0 \mathrm{a}$ & $113.6 \mathrm{a}$ & $112.8 \mathrm{a}$ & $111.5 \mathrm{a}$ & $110.4 \mathrm{a}$ & $109.2 \mathrm{~b}$ \\
\hline Aypek & 115.1 & 113.7 a & $113.1 \mathrm{a}$ & $112.6 \mathrm{a}$ & $111.8 \mathrm{a}$ & 111.7 a & $110.5 \mathrm{a}$ \\
\hline Fresh & 115.1 & $113.6 \mathrm{a}$ & $113.4 \mathrm{a}$ & $112.4 \mathrm{a}$ & $111.6 \mathrm{a}$ & 111.7 a & $110.3 \mathrm{a}$ \\
\hline FreshPlus & 115.1 & $113.4 \mathrm{a}$ & $113.4 \mathrm{a}$ & $112.3 \mathrm{a}$ & 111.9 a & $111.6 \mathrm{a}$ & $110.1 \mathrm{a}$ \\
\hline
\end{tabular}

Means in columns with the same letter do not differ according to Tukey's test at $\mathrm{P}<0.05$

\section{Fruit Firmness}

Fruit firmness is the most significant fruit quality characteristic, which affects storage period and fruit softening (Pekmezci et al., 2004). Many physiological processes such as swelling and deterioration of cell walls, hydrolysis of starch, decrease in water and osmotic potential cause softening in kiwifruit (Redgwell and Fry, 1993). MAP treatments combined with cold storage are effectively used to prolong fruit shelf life and are very useful treatments. With the MAP treatment, the modified atmosphere, which has a low oxygen content, carbon dioxide content and high moisture, is formed around the product (Guilbert et al., 1996). This modified atmosphere reduces the respiration rate and the ethylene production and thus maintains the fruit quality characteristics such as fruit firmness, fruit color, SSC, etc. (Ahvenainen 1996; Gorny, 1997). In the present study, it has been determined that as the storage period is longer fruit firmness decreases, but MAP treatment has influence in maintaining fruit firmness both in storage and 
post-storage shelf period. However, there were no significant differences between MAP treatments in this respect (Table 7). Kaynas et al. (2010); Giacalone and Chiabrando (2013);
Guillen et al.(2013) and Ağlar et al. (2017) reported that MAP treatment had positive effect on preserving fruit firmness during storage.

Table 7. Effects of different modified atmosphere packaging on fruit firmness of kiwifruit during cold storage and shelf life

\begin{tabular}{|c|c|c|c|c|c|c|c|}
\hline \multirow[t]{3}{*}{ Treatments } & \multicolumn{7}{|c|}{ Fruit firmness $(\mathrm{N})$} \\
\hline & \multicolumn{7}{|c|}{ Cold storage $\left(0^{\circ} \mathrm{C}\right)$} \\
\hline & Harvest & 30 & 60 & 90 & 120 & 150 & 180 \\
\hline Control & 80.26 & $45.45 \mathrm{~b}$ & $29.88 \mathrm{~b}$ & $20.43 \mathrm{c}$ & $13.57 \mathrm{~b}$ & $12.13 \mathrm{~b}$ & $9.15 \mathrm{~b}$ \\
\hline Xtend & 80.26 & $61.90 \mathrm{a}$ & $37.83 \mathrm{a}$ & $24.94 \mathrm{~b}$ & $20.14 \mathrm{a}$ & $15.40 \mathrm{a}$ & $11.67 \mathrm{a}$ \\
\hline Aypek & 80.26 & $60.56 \mathrm{a}$ & $34.69 \mathrm{a}$ & $26.73 \mathrm{~b}$ & $18.79 \mathrm{a}$ & $14.27 \mathrm{a}$ & $11.35 \mathrm{a}$ \\
\hline Fresh & 80.26 & $62.42 \mathrm{a}$ & $37.87 \mathrm{a}$ & $25.01 \mathrm{~b}$ & $19.16 \mathrm{a}$ & $14.91 \mathrm{a}$ & $11.18 \mathrm{a}$ \\
\hline \multirow[t]{3}{*}{ FreshPlus } & 80.26 & $62.85 \mathrm{a}$ & $40.58 \mathrm{a}$ & $35.28 \mathrm{a}$ & $21.19 \mathrm{a}$ & $14.39 \mathrm{a}$ & $11.46 \mathrm{a}$ \\
\hline & \multicolumn{7}{|c|}{ Shelf life $\left(21^{\circ} \mathrm{C}\right)$} \\
\hline & Harvest+5 & $30+5$ & $60+5$ & $90+5$ & $120+5$ & $150+5$ & $180+5$ \\
\hline Control & 71.63 & $33.06 \mathrm{c}$ & $18.67 \mathrm{~b}$ & $12.49 \mathrm{~b}$ & $11.74 \mathrm{~b}$ & $10.54 \mathrm{~b}$ & $7.71 \mathrm{~b}$ \\
\hline Xtend & 71.63 & $59.64 \mathrm{a}$ & $23.99 \mathrm{a}$ & $15.92 \mathrm{a}$ & $13.28 \mathrm{a}$ & $12.85 \mathrm{a}$ & $10.86 \mathrm{a}$ \\
\hline Aypek & 71.63 & $47.68 \mathrm{~b}$ & $24.37 \mathrm{a}$ & $15.24 \mathrm{a}$ & $14.45 \mathrm{a}$ & $12.43 \mathrm{a}$ & $10.17 \mathrm{a}$ \\
\hline Fresh & 71.63 & $48.56 \mathrm{~b}$ & $27.40 \mathrm{a}$ & $14.85 \mathrm{a}$ & $13.79 \mathrm{a}$ & $12.10 \mathrm{a}$ & $10.59 \mathrm{a}$ \\
\hline FreshPlus & 71.63 & $58.47 \mathrm{a}$ & $24.24 \mathrm{a}$ & $17.17 \mathrm{a}$ & $14.65 \mathrm{a}$ & $13.15 \mathrm{a}$ & $10.73 \mathrm{a}$ \\
\hline
\end{tabular}

Means in columns with the same letter do not differ according to Tukey's test at $\mathrm{P}<0.05$

\section{SSC, Titratable Acidity and Vitamin C}

In the study it has observed that with increase in period of storage SSC amount increases as well, but titratable acidity decreases. Compared to the control group, MAP treatments had significant effects on changes in SSC and titratable acidity parameters both during storage and post-storage shelf life. However, there were no significant differences between MAP treatments in this respect (Table 8 and 9).

As a matter of fact, Zhang et al. (2003) and Diaz-Mula et al. (2012) have determined that MAP treatments slow down the SSC increase by slowing down fruit ripening in kiwifruit and sweet cherry. However, there are studies, which state MAP treatment does not have a significant effect the SSC value of sweet cherry (Tian et al., 2002, 2004).

It has observed that as storage period increased, vitamin $\mathrm{C}$ amount decreased. In storage and shelf life it was determined that MAP treatment was influential in preserving vitamin $\mathrm{C}$ concentration and significant differences were observed between different MAP treatments in this respect. 
Table 8. Effects of different modified atmosphere packaging on SSC of kiwifruit during cold storage and shelf life

\begin{tabular}{|c|c|c|c|c|c|c|c|}
\hline \multirow[t]{3}{*}{ Treatments } & \multicolumn{7}{|c|}{$\operatorname{SSC}(\%)$} \\
\hline & \multicolumn{7}{|c|}{ Cold storage $\left(0^{\circ} \mathrm{C}\right)$} \\
\hline & Harvest & 30 & 60 & 90 & 120 & 150 & 180 \\
\hline Control & 3.90 & $8.47 \mathrm{a}$ & $10.92 \mathrm{a}$ & $11.93 \mathrm{a}$ & $12.47 \mathrm{a}$ & $12.97 \mathrm{a}$ & $13.40 \mathrm{a}$ \\
\hline Xtend & 3.90 & $7.60 \mathrm{~b}$ & $10.00 \mathrm{~b}$ & $10.50 \mathrm{~b}$ & $11.00 \mathrm{~b}$ & $11.83 \mathrm{~b}$ & $12.60 \mathrm{~b}$ \\
\hline Aypek & 3.90 & $7.53 \mathrm{~b}$ & $10.05 \mathrm{~b}$ & $10.57 \mathrm{~b}$ & $11.33 \mathrm{~b}$ & $11.45 \mathrm{~b}$ & $12.30 \mathrm{~b}$ \\
\hline Fresh & 3.90 & $7.50 \mathrm{~b}$ & $10.17 \mathrm{~b}$ & $10.83 \mathrm{~b}$ & $11.70 \mathrm{~b}$ & $11.80 \mathrm{~b}$ & $12.00 \mathrm{~b}$ \\
\hline \multirow[t]{3}{*}{ FreshPlus } & 3.90 & $7.27 \mathrm{~b}$ & $10.12 \mathrm{~b}$ & $10.73 \mathrm{~b}$ & $11.23 \mathrm{~b}$ & $11.90 \mathrm{~b}$ & $12.15 \mathrm{~b}$ \\
\hline & \multicolumn{7}{|c|}{ Shelf life $\left(21^{\circ} \mathrm{C}\right)$} \\
\hline & Harvest +5 & $30+5$ & $60+5$ & $90+5$ & $120+5$ & $150+5$ & $180+5$ \\
\hline Control & 4.95 & $10.77 \mathrm{a}$ & $12.33 \mathrm{a}$ & $13.45 \mathrm{a}$ & $13.80 \mathrm{a}$ & $14.30 \mathrm{a}$ & $14.55 \mathrm{a}$ \\
\hline Xtend & 4.95 & $8.73 \mathrm{~b}$ & $11.33 \mathrm{~b}$ & $12.25 \mathrm{~b}$ & $12.40 \mathrm{~b}$ & $12.90 \mathrm{~b}$ & $13.80 \mathrm{~b}$ \\
\hline Aypek & 4.95 & $8.77 \mathrm{~b}$ & $11.47 \mathrm{~b}$ & $12.10 \mathrm{~b}$ & $12.80 \mathrm{~b}$ & $13.10 \mathrm{~b}$ & $13.27 \mathrm{~b}$ \\
\hline Fresh & 4.95 & $9.20 \mathrm{~b}$ & $11.35 \mathrm{~b}$ & $12.43 \mathrm{~b}$ & $12.50 \mathrm{~b}$ & $13.15 \mathrm{~b}$ & $13.60 \mathrm{~b}$ \\
\hline FreshPlus & 4.95 & $9.00 \mathrm{~b}$ & $11.20 \mathrm{~b}$ & $12.50 \mathrm{~b}$ & $12.73 \mathrm{~b}$ & $13.20 \mathrm{~b}$ & $13.30 \mathrm{~b}$ \\
\hline
\end{tabular}

Means in columns with the same letter do not differ according to Tukey's test at $\mathrm{P}<0.05$

Table 9. Effects of different modified atmosphere packaging on titratable acidity of kiwifruit during cold storage and shelf life

\begin{tabular}{|c|c|c|c|c|c|c|c|}
\hline \multirow[t]{3}{*}{ Treatments } & \multicolumn{7}{|c|}{ Titratable acidity (g malic acid $100 \mathrm{~g}^{-1}$ ) } \\
\hline & \multicolumn{7}{|c|}{ Cold storage $\left(0^{\circ} \mathrm{C}\right)$} \\
\hline & Harvest & 30 & 60 & 90 & 120 & 150 & 180 \\
\hline Control & 1.85 & $1.60 \mathrm{~b}$ & $1.59 \mathrm{~b}$ & $1.55 \mathrm{~b}$ & $1.51 \mathrm{~b}$ & $1.49 \mathrm{~b}$ & $1.37 \mathrm{~b}$ \\
\hline Xtend & 1.85 & $1.69 \mathrm{a}$ & $1.65 \mathrm{a}$ & $1.63 \mathrm{a}$ & $1.58 \mathrm{a}$ & $1.52 \mathrm{a}$ & $1.47 \mathrm{a}$ \\
\hline Aypek & 1.85 & $1.68 \mathrm{a}$ & $1.64 \mathrm{a}$ & $1.63 \mathrm{a}$ & $1.60 \mathrm{a}$ & $1.54 \mathrm{a}$ & $1.50 \mathrm{a}$ \\
\hline Fresh & 1.85 & $1.72 \mathrm{a}$ & $1.67 \mathrm{a}$ & $1.61 \mathrm{a}$ & $1.57 \mathrm{a}$ & $1.53 \mathrm{a}$ & $1.47 \mathrm{a}$ \\
\hline \multirow[t]{3}{*}{ FreshPlus } & 1.85 & $1.70 \mathrm{a}$ & $1.65 \mathrm{a}$ & $1.60 \mathrm{a}$ & $1.59 \mathrm{a}$ & $1.54 \mathrm{a}$ & $1.45 \mathrm{a}$ \\
\hline & \multicolumn{7}{|c|}{ Shelf life $\left(21^{\circ} \mathrm{C}\right)$} \\
\hline & Harvest +5 & $30+5$ & $60+5$ & $90+5$ & $120+5$ & $150+5$ & $180+5$ \\
\hline Control & 1.80 & $1.58 \mathrm{~b}$ & $1.51 \mathrm{~b}$ & $1.49 \mathrm{~b}$ & $1.44 \mathrm{~b}$ & $1.41 \mathrm{~b}$ & $1.32 \mathrm{~b}$ \\
\hline Xtend & 1.80 & $1.66 \mathrm{a}$ & $1.59 \mathrm{a}$ & $1.55 \mathrm{a}$ & $1.50 \mathrm{a}$ & $1.48 \mathrm{a}$ & $1.34 \mathrm{~b}$ \\
\hline Aypek & 1.80 & $1.64 \mathrm{a}$ & $1.58 \mathrm{a}$ & $1.56 \mathrm{a}$ & $1.54 \mathrm{a}$ & $1.50 \mathrm{a}$ & $1.46 \mathrm{a}$ \\
\hline Fresh & 1.80 & $1.68 \mathrm{a}$ & $1.61 \mathrm{a}$ & $1.54 \mathrm{a}$ & $1.51 \mathrm{a}$ & $1.50 \mathrm{a}$ & $1.33 \mathrm{~b}$ \\
\hline FreshPlus & 1.80 & $1.67 \mathrm{a}$ & $1.62 \mathrm{a}$ & $1.57 \mathrm{a}$ & $1.51 \mathrm{a}$ & $1.49 \mathrm{a}$ & $1.43 \mathrm{a}$ \\
\hline
\end{tabular}

Means in columns with the same letter do not differ according to Tukey's test at $\mathrm{P}<0.05$ 
Table 10. Effects of different modified atmosphere packaging on vitamin $\mathrm{C}$ of kiwifruit during cold storage and shelf life

\begin{tabular}{|c|c|c|c|c|c|c|c|}
\hline \multirow[t]{3}{*}{ Treatments } & \multicolumn{7}{|c|}{ Vitamin C (mg $\left.100 \mathrm{~g}^{-1}\right)$} \\
\hline & \multicolumn{7}{|c|}{ Cold storage $\left(0^{\circ} \mathrm{C}\right)$} \\
\hline & Harvest & 30 & 60 & 90 & 120 & 150 & 180 \\
\hline Control & 127.0 & $119.0 \mathrm{c}$ & $66.5 \mathrm{c}$ & $55.5 \mathrm{c}$ & $46.0 \mathrm{c}$ & $42.0 \mathrm{~b}$ & $38.5 \mathrm{c}$ \\
\hline Xtend & 127.0 & $129.0 \mathrm{~b}$ & $92.5 \mathrm{a}$ & $64.0 \mathrm{~b}$ & $52.0 \mathrm{~b}$ & $48.0 \mathrm{a}$ & $43.0 \mathrm{~b}$ \\
\hline Aypek & 127.0 & $128.0 \mathrm{~b}$ & $76.5 \mathrm{~b}$ & $72.0 \mathrm{a}$ & $60.5 \mathrm{a}$ & $47.0 \mathrm{a}$ & $42.2 \mathrm{~b}$ \\
\hline Fresh & 127.0 & $131.0 \mathrm{~b}$ & $77.5 \mathrm{~b}$ & $62.5 \mathrm{~b}$ & $59.5 \mathrm{a}$ & $50.0 \mathrm{a}$ & $48.0 \mathrm{a}$ \\
\hline \multirow[t]{3}{*}{ FreshPlus } & 127.0 & $142.0 \mathrm{a}$ & $88.0 \mathrm{a}$ & $66.5 \mathrm{~b}$ & $54.0 \mathrm{~b}$ & $49.5 \mathrm{a}$ & $47.5 \mathrm{a}$ \\
\hline & \multicolumn{7}{|c|}{ Shelf life $\left(21^{\circ} \mathrm{C}\right)$} \\
\hline & Harvest+5 & $30+5$ & $60+5$ & $90+5$ & $120+5$ & $150+5$ & $180+5$ \\
\hline Control & 98.1 & $69.0 \mathrm{c}$ & $56.0 \mathrm{c}$ & $50.0 \mathrm{c}$ & $42.0 \mathrm{c}$ & $34.5 \mathrm{~b}$ & $28.5 \mathrm{~b}$ \\
\hline Xtend & 98.1 & $89.0 \mathrm{a}$ & $70.0 \mathrm{a}$ & $59.5 \mathrm{a}$ & $49.5 \mathrm{~b}$ & $43.0 \mathrm{a}$ & $30.0 \mathrm{~b}$ \\
\hline Aypek & 98.1 & $77.5 \mathrm{~b}$ & $69.0 \mathrm{a}$ & $61.0 \mathrm{a}$ & $57.0 \mathrm{a}$ & $44.5 \mathrm{a}$ & $37.0 \mathrm{a}$ \\
\hline Fresh & 98.1 & $80.0 \mathrm{~b}$ & $62.5 \mathrm{~b}$ & $60.5 \mathrm{a}$ & $50.5 \mathrm{~b}$ & $44.5 \mathrm{a}$ & $36.5 \mathrm{a}$ \\
\hline FreshPlus & 98.1 & $79.5 \mathrm{~b}$ & $64.0 \mathrm{~b}$ & $54.5 \mathrm{~b}$ & $48.5 \mathrm{~b}$ & $46.5 \mathrm{a}$ & $39.0 \mathrm{a}$ \\
\hline
\end{tabular}

Means in columns with the same letter do not differ according to Tukey's test at $\mathrm{P}<0.05$.

At the end of storage, while the lowest vitamin $\mathrm{C}$ concentration was observed in control group fruit, the highest values were observed with Fresh and FreshPlus treatments (Table 10). Tian et al. (2004) and Ağlar et al. (2017) determined that in sweet cherry, vitamin C content decreased during cold storage, and vitamin C content of MAP-treated fruit were higher than control treatment, Again, Mohammadi and Hanafi (2014) reported that MAP-treated fruit in strawberry had higher values for vitamin $\mathrm{C}$ content.

\section{CONCLUSION}

As a result, it was determined that MAP treatment was an effective tool to prevent postharvest quality losses in kiwifruit. Alos the effects of MAP treatments on the fruit quality characteristics varied depending on the MAP material used.

\section{REFERENCES}

Aglar E, Ozturk B, Guler SK, Karakaya O, Uzun S, Saracoglu O, 2017. Effect of modified atmosphere packaging and 'Parka' treatments on fruit quality characteristics of sweet cherry fruits (Prunus avium L. '0900 Ziraat') during cold storage and shelf life. Scientia Horticulturae 222 (2017):162-168

Ahvenainen R, 1996. New approaches in improving the shelf life of minimally processedfruit and vegetables. Trends in Food Science and Technology, 179-197.

Artes-Hernandez, F., Tomas-Barberan, F.A., Artes, F., 2006. Modified atmosphere packaging preserves quality of SO2-free 'Superior seedless' table grapes. Postharvest Biology Technology. 39, 146-154.

Cantín CM, Crisosto CH, Day KR, 2008. Evaluation of the effect of different modifiedatmosphere packaging box liners on the quality and shelf life of 'Friar' plums. HortTechnology 18: 161165.

Cassano A, Figoli A, Tagarelli A, Sindona G, Drioli E,2006. Integrated membrane process for the production of highly nutritional kiwifruit juice. esalination, 189: 21-30. 
Castellanos DA, Polanía W, Herrera AO, 2016. Development of an equilibrium modified atmosphere packaging (EMAP) for feijoa fruits and modeling firmness and color evolution. Postharvest Biology and Technology, 120: 193-203.

Chiabrando V, Giacalone G, 2015. Effects of alginate edible coating on quality and antioxidant properties in sweet cherry during postharvest storage. Italian Journal of Food Science, 27: 173-180.

Diaz-Mula HM, Serano M, Valero D, 2012. Alginate Coatings Preserve Fruit Quality and Bioactive Compounds during Storage of Sweet Cherry Fruit. Food and Bioprocess Technology $5(8): 1-8$

Domínguez I, Lafuente MT, Hernández-Muñoz P, Gavara R, 2016. Influence of modified atmosphere and ethylene levels on quality attributes of fresh tomatoes (Lycopersicon esculentum Mill.). Food Chemistry. 209: 211219.

Fonseca SC, Oliveira FAR, Brecht JK, 2002. Modelling respiration rate of fresh fruits and vegetables for modified atmosphere packages: a review. Jornal of Food Enginering. 52: 99119.

Giacalone G, Chiabrando V, 2013. Modified atmosphere packaging of sweet cherries with biodegradable films International Food Research Journal. 20: 1263-1268.

Gorny JR,1997. A summary of CA and MA requirements and recommendations for the storage of fresh-cut (minimally processed) fruits and vegetables. In J. R. Gorny (Vol. Ed.), Proceedings [Seventh International Controlled Atmosphere Research Vol. 5: 30 66.

Guilbert S, Gontard N, Gorris LGM, 1996. Prolongation of the shelf life of perishable food products using biodegradable films and coatings. Food Science and Technology. 29: $10-17$.

Guillen F, Diaz-Mula HM, Zapata PJ, Valero D, Serrano M, Castillo S, Martinez-Romero D, 2013. Aloe arborescens and Aloe vera gels as coatings in delaying postharvest ripening in peach and plum fruit. Postharvest Biology and Technology. 83: 54-57.
Kaynas K, Sakaldas M, Yur M., 2010. The effects of different postharvest applications and different modified atmosphere packaging types on fruit quality of 'Angeleno' plums. Acta Horticulturae. 876: 209-216.

Mendoza R, Castellanos DA, García JC, Vargas JC, Herrera AO, 2016. Ethylene production, respiration and gas exchange modelling in modified atmosphere packaging for banana fruits. Interationl Journal of Food Science and Technology. 51 (3): 777-788.

Mohammadi H, Hanafi Q, 2014. Effect of different atmospheres on quality changes of Kurdistan strawberry. Journal of Food Chemistryand Nutrition. 2: 61-69.

Pekmezci M, Erkan M, GubbukM, Karasahin I,Uzun I,2004. Modified atmosphere and ethylene absorbent enables prolonged storage of Hayward kiwifruit. In: L.G. Albrigo, V. Galan Sauco (Editors), XXVI International Horticultural Congress: Citrus and Other Subtropical and Tropical Fruit Crops, Canada 29 February, 2004. Acta Hortculturae. 632: 337-341.

Petracek PD, Joles DW, Shirazi A, Cameron AC, 2002. Modified atmosphere packaging of sweet cherry (Prunus avium L. ev.'Sams') fruit: metabolic responses to oxygen, carbon dioxide, and temperature. Postharvest Biology and Technology. 24: 259-270.

Redgwell RJ, Fry SC, 1993. Xyloglucan Endotransglycosylase Activity Increases during Kiwifruit (Actinidia deliciosa) Ripening (Implications for Fruit Softening). Plant Physiology (1993) 103: 1399-1406.

Saltveit ME, 1997. A summary of CA and MA requirements and recommendations for harvested vegetables. In M. E. Saltveit (Ed.), Proceedings of the 7th international controlled atmosphere research conference: Vol. 4 (pp. 98-117), Davis, CA, USA.

Tian SP, Xu Y, Jiang AL, Gong QQ, 2002. Physiological and quality responses of longan fruits to high-O2 or high-CO2 atmospheres in storage. Postharvest Biology andTechnology. 24: 335-340.

Tian SP, Jiang AL, Xu Y, Wang YS, 2004. Responses of physiology and quality of sweet cherry fruit to different atmosphere in storage. Food Chemistry. 87: 43-49. 
Valero D, Mirdehghan SH, Sayyari M, Serrano M, 2014. Vapor treatments, chilling, storage, and antioxidants in pomegranates. In: Preedy, V.R. (Ed.), Processing and Impact on Active Components in Food. Academic Press, London, pp. 189-196.

Valverde JM, Gimenez MJ, Guillen F, Valero D, Martinez-Romero D, Serrano M,2015. Methyl salicylate treatments of sweet cherry trees increase antioxidant systems in fruit at harvest and during storage. Postharvest Biology and Technology. 109: 106-113.
Yang YJ, Lim BS, 2017. Temperature and length of cold storage affect the Quality Maintenance of fresh kiwifruit (Actinidia chinensis Planch). Journal of the Korea Academia-Industrial cooperation Society, Vol. 18, No. 1 pp. 256261, 2017.

Zhang Y, Chen K, Zhang S, Ferguson I, 2003. The role of salicylic acid in postharvest ripening of kiwifruit. Postharvest Biology and Technology, $28: 67-74$. 